\title{
Astyanax argyrimarginatus Garutti, 1999 (Characiformes: Characidae): First Xingu basin distribution record and geographic distribution map
}

\author{
Marcelo Andrade ${ }^{1 *}$, Douglas Bastos ${ }^{1,2}$ and Tommaso Giarrizzo ${ }^{1}$ \\ 1 Universidade Federal do Pará (UFPA), Laboratório de Biologia Pesqueira e Manejo dos Recursos Aquáticos, Grupo de Ecologia Aquática. Campus \\ Universitário do Guamá, Avenida Perimetral 2651. CEP 66040-830. Belém, PA, Brazil. \\ 2 Instituto Nacional de Pesquisas da Amazônia (INPA). Avenida André Araújo 2936. CEP 69060-001. Manaus, AM, Brazil. \\ * Corresponding author: E-mail: andrademarcosta@gmail.com
}

\begin{abstract}
We present new records of Astyanax argyrimarginatus Garutti, 1999 for the Xingu basin and distribution extension of approximately 1,000 km towards north-west in Tocantins-Araguaia basin. The species was previously known only from tributary of upper rio Araguaia, Goiás and Mato-Grosso states, Brazil.
\end{abstract}

The Neotropical genus Astyanax Baird and Girard, 1854 includes approximately 90 species whose geographic distributions, although widely recorded in South America, are still poorly understood (Lima et al. 2003; Garutti and Venere 2009). In 1999, Astyanax argyrimarginatus Garutti was described as a new species based on 45 specimens collected from a tributary of the upper rio Araguaia, Goiás and Mato-Grosso states in central Brazil and it remains known only from its locality. Herein, we present the first record of $A$. argyrimarginatus for the Xingu basin and expand the known geographical distribution about 1,000 $\mathrm{km}$ north-westward into the Tocantins-Araguaia basin.

The species mentioned here (Figure 1) belongs to the bimaculatus species complex and shares with these species the following combination of characters: i) black humeral spot horizontally elongated, ii) two diffuse vertical bars in the humeral region, iii) a lateral black stripe that extends to the middle caudal-fin rays, and iv) a large silver stripe extending along the body. It differs, however, from all other congeners by the presence of many scales in lateral line (equal or higher than 42 scales) and one tooth in the maxillary bone (for more information see diagnosis of the species in Garutti 1999 and Garutti and Langeani 2009).

These new records were obtained during field surveys carried out between 2007 and 2010 in small streams of the Carajás National Forest (Floresta Nacional de Carajás), and the Serra Onça Puma, in Southwestern Pará, Brazil (Figure 2).

Collections were made using sieves ( $3 \mathrm{~mm}$ mesh), casting net ( $9 \mathrm{~mm}$ mesh), seines ( $2 \mathrm{~mm}$ mesh) and gillnet (40 $\mathrm{mm}$ mesh). The specimens were preserved in $10 \%$ formalin solution and conserved in $70 \%$ ethanol. Measurements and counts followed essentially Garutti (1999), and were made using a digital caliper nearest to $0.1 \mathrm{~mm}$. Counts were taken under a stereomicroscope (Table 1). Specimens were collected under collection permits 012/2007 and 008/2010 - IBAMA 02047.000384/2007-34 and were deposited at the ichthyology collections of INPA and MPEG (Appendix I).
The expansion of the occurrence area in TocantinsAraguaia basin is represented by the igarapé Motosserra (Figure 3A, 06 $32^{\prime} 33^{\prime \prime} \mathrm{S}, 051^{\circ} 04^{\prime} 55^{\prime \prime} \mathrm{W}$ ) tributary of rio Cateté, and by the rio Cinzento (Figure $3 \mathrm{~B}, 05^{\circ} 51^{\prime} 35^{\prime \prime} \mathrm{S}$, $050^{\circ} 31^{\prime} 24^{\prime \prime}$ W) tributary of rio Itacaiúnas. Furthermore, the new record of occurrence for the Xingu basin is given by igarapé Paxiubal (Figure 3C, 06³6'53" S, 051 15'09" W) and igarapé Mogno (Figure 3D, 06 33'06" S, 051 10'10'59" W), both tributaries of rio Carapanã. All are small clear water tributaries with a mean width and depth of 5.2 and $0.9 \mathrm{~m}$, respectively.

Although a review of the genus Astyanax with consideration toward a larger distribution has not been performed, no differences were found between specimens from the tributaries of Xingu and Tocantins-Araguaia. Despite some variations in the characters found, the specimens can be only identified as A. argyrimarginatus.

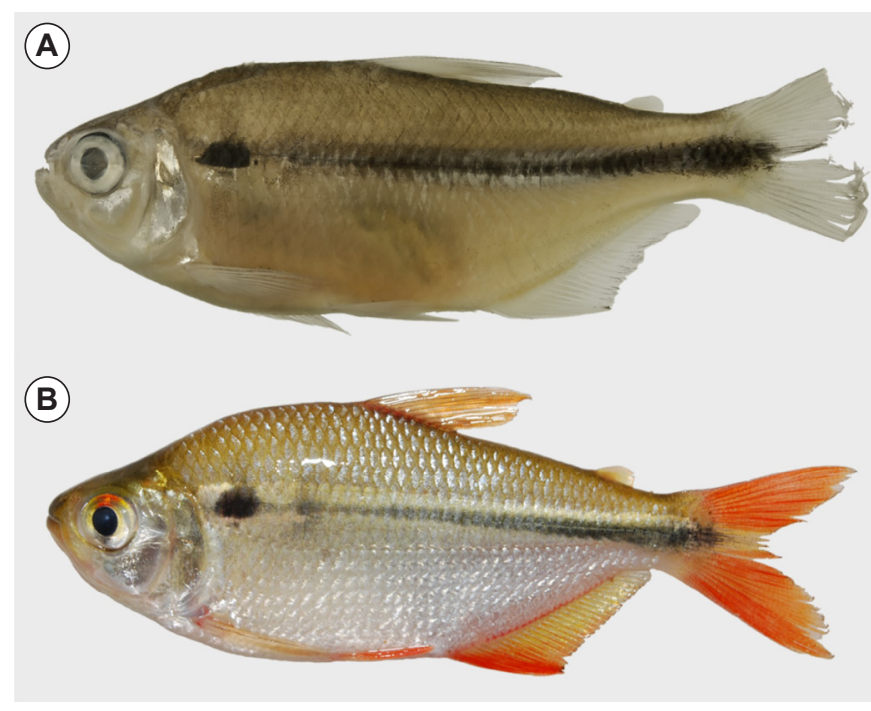

Figure 1. (a) Astyanax argyrimarginatus, INPA 36369, male, $67.6 \mathrm{~mm}$ SL, igarapé Mogno, Pará state, Brazil. (b) Specimen photographed alive, captured in the same locality of voucher INPA 36369 
TABLE 1. Morphometric and meristic data of thirteen specimens Astyanax argyrimarginatus captured on Xingu and Tocantins-Araguaia basins.

\begin{tabular}{|c|c|c|c|c|c|c|}
\hline \multirow[b]{2}{*}{ CHARACTER } & \multicolumn{3}{|c|}{ XINGU BASIN } & \multicolumn{3}{|c|}{ TOCANTINS-ARAGUAIA BASIN } \\
\hline & $\mathbf{N}$ & LOW - HIGH & MEAN \pm SD & $\mathbf{N}$ & LOW - HIGH & MEAN \pm SD \\
\hline Standard length $(\mathrm{mm})$ & 6 & $50.3-72.2$ & $67.2 \pm 8.4$ & 7 & $55.1-102.7$ & $85.3 \pm 14.8$ \\
\hline Head length & 6 & $13.9-19.6$ & $18.0 \pm 2.1$ & 7 & $15.7-26.8$ & $22.9 \pm 3.6$ \\
\hline Body depth & 6 & $18.9-29.8$ & $25.8 \pm 3.8$ & 7 & $23.3-47.1$ & $37.9 \pm 8.5$ \\
\hline Predorsal length & 6 & $25.6-37.5$ & $32.6 \pm 5.5$ & 7 & $29.7-54.0$ & $45.5 \pm 7.6$ \\
\hline Preanal length & 6 & $34.3-51.7$ & $46.4 \pm 6.2$ & 7 & $39.3-71.0$ & $58.6 \pm 10.1$ \\
\hline Dorsal-peitoral distance & 6 & $20.4-31.2$ & $27.8 \pm 3.9$ & 7 & $24.5-47.5$ & $39.5 \pm 7.3$ \\
\hline Dorsal-anal distance & 6 & $20.4-31.1$ & $27.8 \pm 3.8$ & 7 & $23.8-59.1$ & $43.4 \pm 10.6$ \\
\hline Anal-adipose distance & 6 & $19.7-26.8$ & $24.8 \pm 2.6$ & 7 & $22.2-40.0$ & $33.6 \pm 5.6$ \\
\hline Dorsal-adipose distance & 6 & $17.7-28.4$ & $25.7 \pm 4.0$ & 7 & $21.9-41.7$ & $36.1 \pm 6.7$ \\
\hline Orbital diameter & 6 & $5.2-7.5$ & $6.8 \pm 0.8$ & 7 & $5.5-8.7$ & $7.7 \pm 1.1$ \\
\hline Interorbital width & 6 & $4.9-6.9$ & $6.3 \pm 0.8$ & 7 & $5.3-10.7$ & $8.4 \pm 1.6$ \\
\hline Head depth & 6 & $15.9-24.5$ & $21.4 \pm 2.9$ & 7 & $19.1-36.7$ & $29.4 \pm 5.8$ \\
\hline Peduncle depth & 6 & $6.1-8.7$ & $7.8 \pm 0.9$ & 7 & $6.1-12.5$ & $10.3 \pm 2.0$ \\
\hline \multicolumn{7}{|c|}{ PERCENTAGES OF STANDARD LENGTH } \\
\hline Head length & 6 & $25.3-27.5$ & $26.8 \pm 0.9$ & 7 & $25.8-28.5$ & $26.9 \pm 0.9$ \\
\hline Body depth & 6 & $36.8-41.7$ & $38.3 \pm 1.8$ & 7 & $35.4-48.7$ & $44.2 \pm 4.5$ \\
\hline Peduncle depth & 6 & $10.9-12.1$ & $11.7 \pm 0.5$ & 7 & $11.1-12.9$ & $12.0 \pm 0.6$ \\
\hline Predorsal length & 6 & $35.4-52.5$ & $48.8 \pm 6.6$ & 7 & $51.5-55.6$ & $53.4 \pm 1.4$ \\
\hline Preanal length & 6 & $66.3-72.4$ & $69.0 \pm 2.1$ & 7 & $63.9-71.3$ & $68.9 \pm 2.5$ \\
\hline Dorsal-peitoral distance & 6 & $39.6-43.6$ & $41.3 \pm 1.6$ & 7 & $44.5-48.6$ & $46.2 \pm 1.3$ \\
\hline Dorsal-anal distance & 6 & $40.4-43.5$ & $41.4 \pm 1.1$ & 7 & $43.2-68.5$ & $50.6 \pm 8.2$ \\
\hline Anal-adipose distance & 6 & $35.8-39.1$ & $37.0 \pm 1.1$ & 7 & $37.7-40.7$ & $39.5 \pm 0.9$ \\
\hline Dorsal-adipose distance & 6 & $35.1-39.3$ & $38.0 \pm 1.6$ & 7 & $39.8-44.5$ & $42.2 \pm 1.9$ \\
\hline \multicolumn{7}{|c|}{ PERCENTAGES OF HEAD LENGTH } \\
\hline Orbital diameter & 6 & $33.8-40.2$ & $37.8 \pm 2.2$ & 7 & $31.6-35.0$ & $33.7 \pm 1.3$ \\
\hline Interorbital width & 6 & $33.9-36.3$ & $35.2 \pm 0.9$ & 7 & $33.8-39.9$ & $36.6 \pm 2.0$ \\
\hline Head depth & 6 & $114.7-125.1$ & $118.5 \pm 3.9$ & 7 & $112.7-140.8$ & $128.1 \pm 9.8$ \\
\hline \multicolumn{7}{|c|}{ PERCENTAGES OF BODY DEPTH } \\
\hline Peduncle depth & 6 & $28.3-32.6$ & $30.5 \pm 1.7$ & 7 & $24.5-36.6$ & $27.5 \pm 4.1$ \\
\hline COUNTS & $\mathbf{N}$ & LOW - HIGH & MODE & $\mathbf{N}$ & LOW - HIGH & MODE \\
\hline Scales in lateral line (LL) & 6 & $42-46$ & 42 & 7 & $44-46$ & 44 \\
\hline Rows of scales above LL & 6 & $6-9$ & 8 & 7 & $8-10$ & 9 \\
\hline Rows of scales below LL & 6 & $6-7$ & 7 & 7 & $7-8$ & 8 \\
\hline Transverse scales & 6 & $13-17$ & 16 & 7 & $16-19$ & 16 \\
\hline Anal rays & 6 & iii24 - iii28 & Iii28 & 7 & iii23 - iii28 & iii25 \\
\hline
\end{tabular}
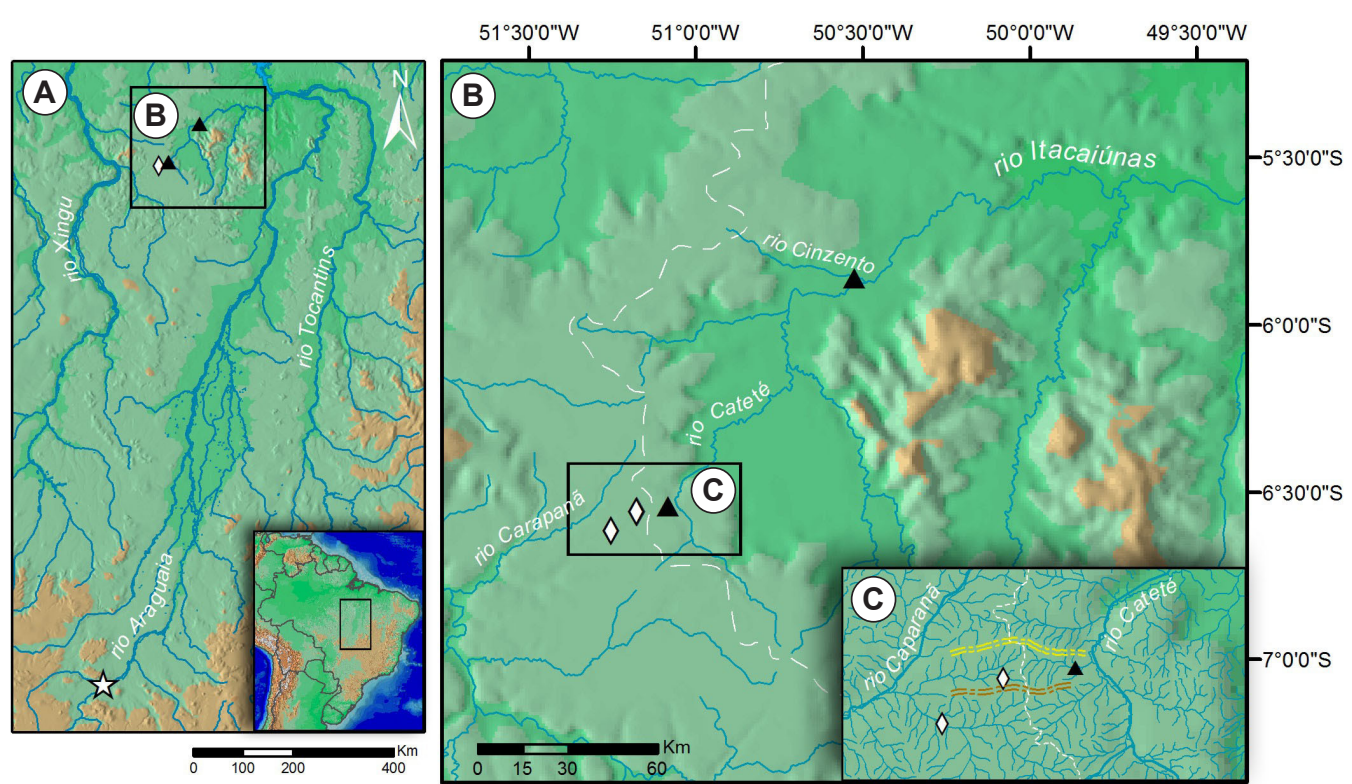

FIGURE 2. Area of distribution of Astyanax argyrimarginatus. (a) The star represents the type locality (Garutti 1999) at rio Araguaia; (b) black triangles represent the new record for Tocantins-Araguaia basin; and (b and c) white diamonds represent the new record for Xingu basin. The dashed white line in figure $b$ and $c$ represents the division of watersheds, at the left has the Xingu basin and at the right has Tocantins-Araguaia. Dashed yellow: Onça mountain range [Serra Onça]. Dashed brown: Puma mountain range [Serra Puma]. 
The species in life presents fins with red color, more intense on the caudal fin and the anterior anal-fin rays (Figure 1B). Bony hooks on anal-fin are hypothetically a synapomorphy of the family Characidae (Malabarba and Weitzman 2003). These structures were detected on anal-fins of mature males (75-107 $\mathrm{mm} T L$ ) captured in February, 2010 (wet season). In these specimens, three have bony hooks on anal-fin of the last unbranched ray to $8^{\text {th }}-11^{\text {th }}$ branched $(50.35-93.59 \mathrm{~mm} S L$, INPA 36370, INPA 36371 and INPA 36372).

We suggest the possibility that this species may be more widely distributed than first thought. Given that the known locality of $A$. argyrimarginatus is more than $1,000 \mathrm{~km}$ away from the newly recorded locations this indicates a wider range within the Tocantins-Araguaia than previously thought. Since one of the new collections is located within the Xingu river basin, we suggest that the species distribution also may include the Xingu, with the possibly that connectivity exists between populations in the two basins. Therefore, new biogeographic directions of ichthyofauna of two main hydrographic basins of South America are indicated.

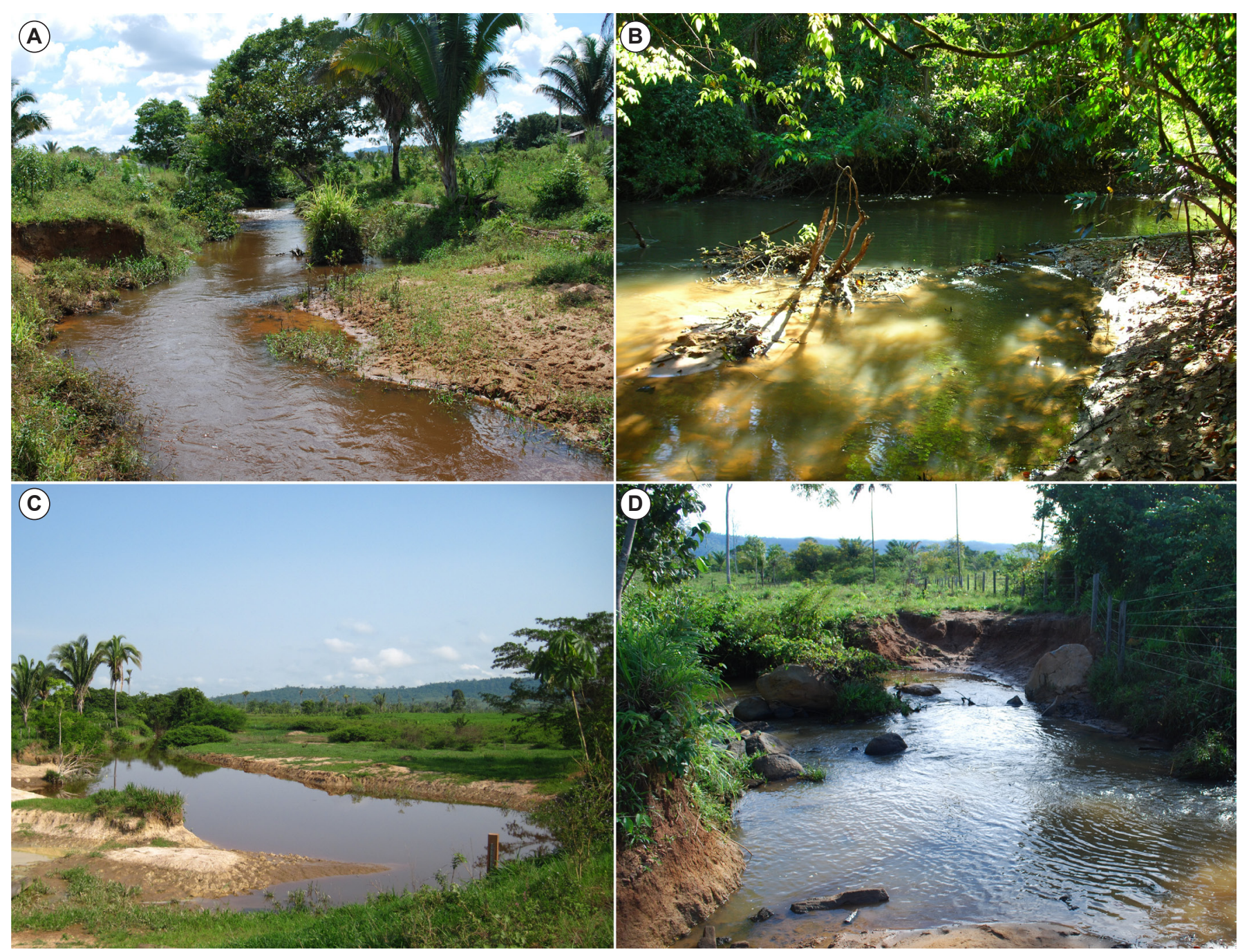

FiguRE 3. Environment where Astyanax argyrimarginatus specimens were recorded. A) igarapé Motosserra, sub-basin of the rio Cateté; B) rio Cinzento, sub-basin of the rio Itacaiúnas; C) igarapé Paxiubal; and D) igarapé Mogno, both from sub-basin of the rio Carapanã.

ACKNOWLEDGMENTS: We thank Thiago Morais, Nelson Balão and Allan Jamesson de Jesus for their assistance in sample collection, and Rafaela Ota by analysis of vouchers deposited at INPA. Thank you to Luiz Peixoto for their help during the visit to collection of fish of the MPEG. We also thank Jens Hegg by the review of English version. This study was funded by CAPES and CNPQ through MSc Fellowship waived to first and second author, respectively.

\section{Literature Cited}

Garutti, V. 1999. Descrição de Astyanax argyrimarginatus sp. $\mathrm{n}$. (Characiformes, Characidae) procedente da bacia do rio Araguaia, Brasil. Revista Brasileira de Biologia 59(4): 585-591.

Garutti, V. and F. Langeani. 2009. Redescription of Astyanax goyacensis Eigenmann, 1908 (Ostariophysi: Characiformes: Characidae). Neotropical ichthyology 7(3): 371-376.

Garutti, V. and P.C. Venere. 2009. Astyanax xavante, a new species of characid from middle rio Araguaia in the Cerrado region, Central Brazil (Characiformes: Characidae). Neotropical Ichthyology 7(3) 377-383.
Lima, F.C.T., L.R. Malabarba, P.A. Buckup, J.F.P. Silva, R.P. Vari, A. Harold, R. Benine, O.T. Oyakawa, C.S. Pavanelli, N.A. Menezes, C.A.S. Lucena, M.C.S.L. Malabarba, Z.M.S. Lucena, R.E.Reis, F. Langeani, L. Casatti, V.A. Bertaco, C. Moreira and P.H.F. Lucinda. 2003. Genera Incertae Sedis in Characidae; p. 106-169 In R.E. Reis, S.O. Kullander and C.J. Ferraris-Jr. (ed.), Check List of the Freshwater Fishes of South and Central America. Porto Alegre: Edipucrs.

Malabarba, L.R. and S.H. Weitzman. 2003. Description of a new genus with six new species from southern Brazil, Uruguay and Argentina, with a discussion of a putative characid clade (Teleostei: Characiformes: Characidae). Comunicações do Museu de Ciências e Tecnologia da PUCRS Série Zoologia 16(1): 67-151.

RECEIVED: January 2012

ACCEPTED: july 2012

Published ONLINE: August 2012

EDITORIAL RESPONSIBILITY: Rubens Pazza 